\title{
Variability of the Stratification and Circulation on the Flemish Cap during the Decades of the 1950s-1990s
}

\author{
E. B. Colbourne and K. D. Foote \\ Department of Fisheries and Oceans, P. O. Box. 5667 \\ St. John's, Newfoundland, Canada A1C 5X1
}

\begin{abstract}
Oceanographic observations on the Flemish Cap (around $47^{\circ} \mathrm{N}, 45^{\circ} \mathrm{W}$ ) from the early-1990s to 1999 are compared to the long-term mean and to conditions during the past several decades. The mean temperature and salinity fields and their seasonal cycles were first computed and then used to construct T/S anomaly time series. The data shows a relatively warm time period from the 1950s through the 1960s and three colder-than-normal periods since the early-1970s. In general, it was found that variations in water properties on the Flemish Cap are highly correlated with those observed in the inshore branch of the Labrador Current at Station 27 and in other areas of the Newfoundland Continental Shelf. Studies have shown that these conditions are linked to the largescale atmospheric winter circulation, sea ice conditions, local atmospheric forcing and advection. An examination of local air-sea heat flux indicate that advection of Labrador Current water into the region may be the principle cause of oceanic variability over the Flemish Cap. An examination of recent acoustic Doppler current measurements and geostrophic current calculations indicated the predominance of an anticyclonic gyre circulation around the Flemish Cap during the summer and a significant and persistent Labrador Current component to the circulation. The results, however, exhibited a high degree of interannual variability.
\end{abstract}

Keywords: Flemish Cap, oceanography, temperature, salinity, currents.

\section{Introduction}

The Flemish Cap is located east of the Grand Bank of Newfoundland centered at about $47^{\circ} \mathrm{N}, 45^{\circ} \mathrm{W}$ (Fig. 1) in NAFO Div. 3M. Minimum water depths on the Flemish Cap are about $150 \mathrm{~m}$. The Cap has a diameter at the $500 \mathrm{~m}$ isobath of about $200 \mathrm{~km}$ and a total area of approximately $3.0 \times 10^{4} \mathrm{~km}^{2}$. To the west, the Flemish Pass with water depths of about $1100 \mathrm{~m}$, separates the Cap from Grand Bank of Newfoundland. At the $2000 \mathrm{~m}$ isobath the Flemish Cap appears as an eastward extension of the Newfoundland Continental Shelf. The water mass on and around the Flemish Cap is comprised mainly of two sources; North Atlantic Current water, with temperatures $>4^{\circ} \mathrm{C}$ and salinities $>34.8$, flowing from the south and Labrador Current Slope water, with temperatures between $3-4^{\circ} \mathrm{C}$ and salinities between $34-35$, flowing from the north. Akenhead (1986) provided evidence that Labrador Current was the sole source of water within the upper $100 \mathrm{~m}$ depth range on the Cap itself. The general circulation in the vicinity of the Flemish Cap is shown in Fig. 2. The water properties on the Flemish Cap are subjected to large annual and interannual variations due to storm forced mixing, variations in atmosphere-ocean heat flux and through advection. The seasonally modified water mass has a lower temperature range than that over the adjacent Grand Bank with temperatures at depth ranging from $3^{\circ}$ to $4^{\circ} \mathrm{C}$ throughout the year (Colbourne and Senciall, 1996). Surface temperatures on the Cap range from a minimum of $3^{\circ} \mathrm{C}$ during winter to above $13^{\circ} \mathrm{C}$ during summer, as a result the region is relatively ice free, with pack ice encroaching only briefly during February and March of severe ice years.

Templeman (1976) provided a background of the biology and hydrography of Flemish Cap area in preparation for a multinational research effort aimed at understanding the physical and biological processes controlling fish production. Data collection for that research effort was carried out from mid-1970s to early-1980s under the auspices of the International Commission for the Northwest Atlantic Fisheries (ICNAF). Much of what is known today about the oceanography on the Flemish Cap was determined from those data sets. Akenhead (1986) described water retention over the Cap and Loder et al. (1988) characterized the time and space scales of circulation and mixing on the Flemish Cap. Stein (1996) presented an overview of most of the research results on the thermohaline properties and water mass 


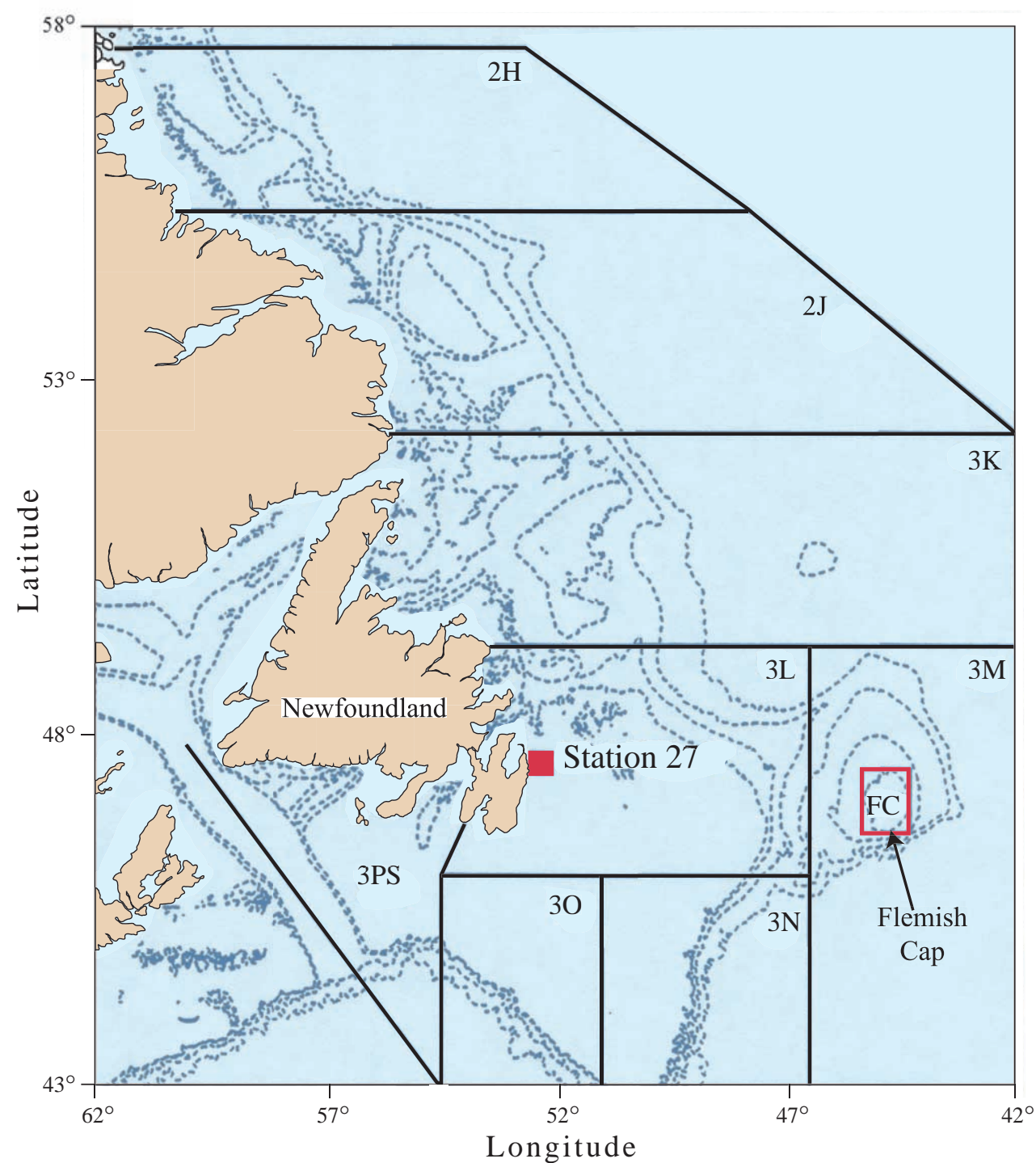

Fig. 1. Regional location map, showing the location of the Flemish Cap area. The box labelled FC corresponds to the area where temperature, salinity and air-sea heat flux time series were constructed. Bathymetry lines are 300, 1000 and $2000 \mathrm{~m}$. The position of Station 27 is also shown.

circulation on Flemish Cap that were completed during this project. A comprehensive bibliography is presented in Stein's (1996) overview. Drinkwater and Trites (1986) published spatially averaged temperature and salinity from all available bottle data from 1910 to 1982 over the Flemish Cap area. More recent reviews of oceanographic conditions in the region, compared data from 1993 to 1998 with the long-term mean (Colbourne, MS 1993; MS 1995; MS 1996; MS 1997; MS 1998). These reviews were based mainly on data collected on the Cap during annual summer oceanographic surveys and a limited amount of data collected on Canadian fish assessment surveys.
Several research studies and annual oceanographic reviews have shown that since the early1970s, the oceanographic and sea ice conditions in the Northwest Atlantic in general, have been dominated by near-decadal oscillations (Colbourne $e t$ al., 1994; Drinkwater, 1996; Drinkwater et al., 1996). The results of these studies show a strong correlation between the winter atmospheric circulation in the North Atlantic and ocean conditions. It was found that winters with high North Atlantic Oscillation (NAO) (Rogers, 1984) index corresponded to increased winter northwesterly winds over eastern Canada. This circulation brought colder-than-normal 


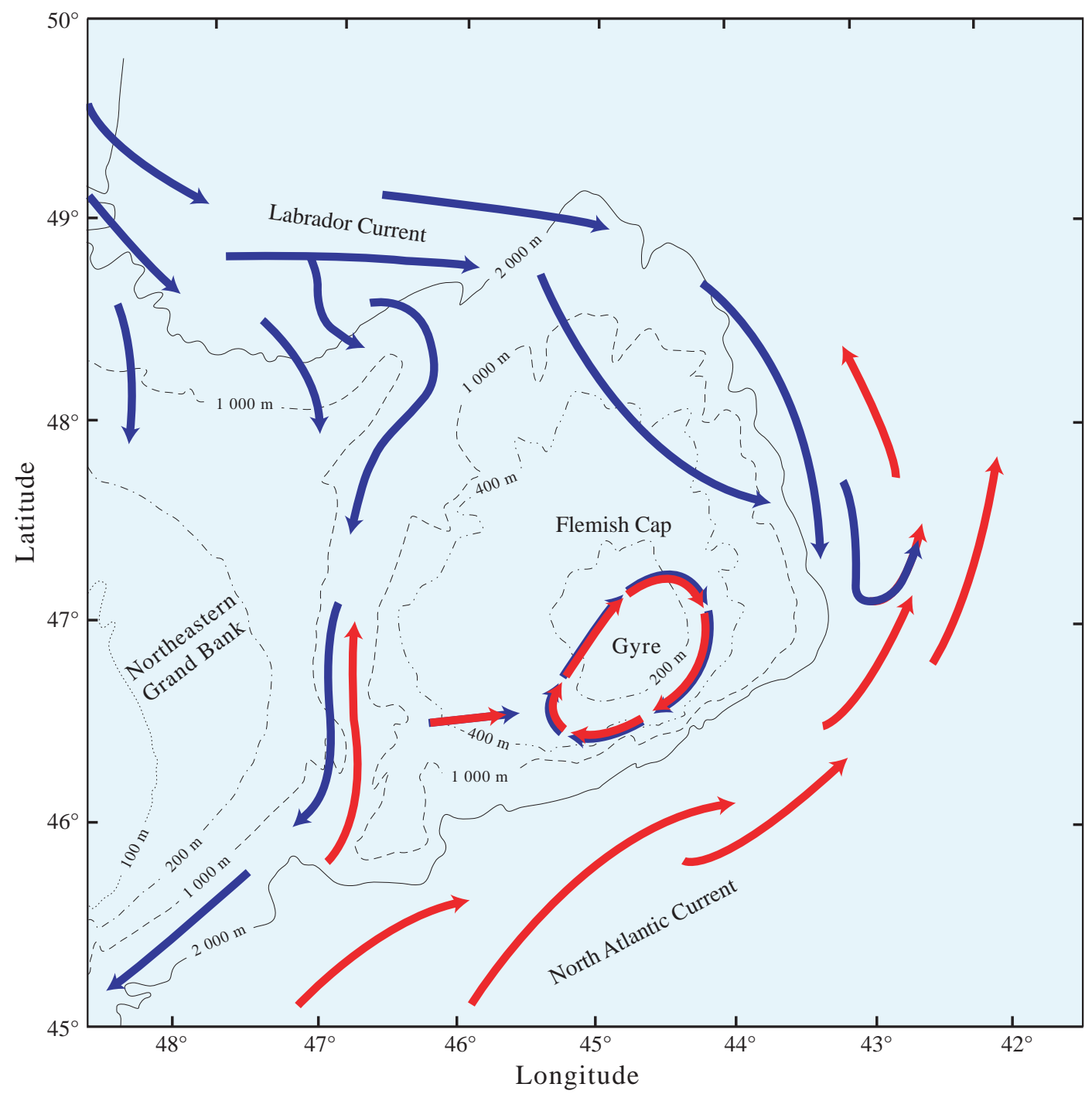

Fig. 2. A schematic indicating the major circulation features around the Flemish Cap (Adapted from Anderson, 1984).

air temperatures to Atlantic Canada resulting in increased ice cover and colder and fresher-thannormal oceanographic conditions to the continental shelves of Atlantic Canada during the early-1970s, mid-1980s and early-1990s.

In this paper we describe the oceanographic variability on the Flemish Cap in relation to the standard reference period 1961-90 in accordance with the World Meteorological Organization. Of particular interest is the extent to which variability in Flemish Cap water properties compared with those on the Newfoundland Shelf, at Station 27 for example (Fig. 1 ), during the cold period of the early-1990s. The relative importance of local air-sea heat fluxes, advection and other processes on the Cap will be addressed. The general circulation on and around the Cap is reviewed with some new observations and analysis.

\section{Circulation on Flemish Cap}

\section{General}

The first evidence that the Labrador Current contributed to the general circulation in the vicinity of the Flemish Cap was provided by Smith et al. (1937) and later confirmed by Buzdalin and Elizarov (1962). They observed a bifurcation in the Labrador Current in the vicinity of the Northern Grand Bank of Newfoundland. A component of the Labrador Current flowed to the east along the northern slopes of the Cap while the remainder flowed south through 
the Flemish Pass along the eastern slopes of the Grand Bank. Kudlo and Burmakin (1972) provided evidence that the circulation on the centre of the Cap was generally clockwise, this was later supported by observations by Hill et al. (MS 1973). The general view of the circulation at present is that two major current systems dominate the circulation and influence the water mass properties on and around the Flemish Cap; the Labrador Current and the North Atlantic Current. The offshore component of the Labrador Current as mentioned above flows to the south through the Flemish Pass and to the east and southeast around the northern and eastern slopes of the Cap. This flow transports cold, relatively low salinity Labrador Slope water into the region. To the southeast the North Atlantic Current transports warmer, high salinity water to the northeast along the southeast slope of Grand Bank and the Flemish Cap (Fig. 2). The circulation over the center of the Cap is dominated by an anticyclonic gyre (Kudlo et al., 1984, Ross, 1981) which frequently forms when an incident current in a stratified fluid interacts with an isolated topographical feature through a redistribution of vorticity (Huppert and Bryan, 1976). The thermohaline properties of the water mass over the Cap, within the gyre, consists of seasonally modified Labrador Current water, while the properties at greater depths along the periphery of the bank, especially along the south and eastern slopes, are derived from a mixture of Labrador Current and North Atlantic water.

The available data on the Flemish Cap indicate very weak mean flows, with surface currents generally less than $15 \mathrm{~cm} / \mathrm{sec}$ (Ross, 1981) and deeper water currents $(185 \mathrm{~m})$ about $3 \mathrm{~cm} / \mathrm{sec}$, with standard deviations of near $10 \mathrm{~cm} / \mathrm{sec}$ at $185 \mathrm{~m}$ depth. Most of this variability (70\%) is associated with the high frequency components (less than 18 hours) (Ross, 1981 and Loder et al., 1988). While both drifting buoy data (Ross, 1981) and geostrophic calculations (Kudlo et al., 1984) showed evidence of clockwise motion, even during the winter months, they also indicate frequent breakdown of the gyre circulation. For example, out of 6 buoys deployed on the Cap during 1979-80 only one executed a complete re-circulation and the average time the buoys remained on the Cap was 50 days. Also, out of 27 hydrographic surveys conducted on the Cap between 1977-82 only about $67 \%$ showed evidence of some degree of anticyclonic circulation (Kudlo et al., 1984).

The stability of the gyre circulation on the Cap is strongly influenced by atmospheric forcing at weather band frequencies (about 2-10 days). Kudlo et al. (1984) showed that the flow over the Cap consisted of several types of circulation patterns ranging from pronounced gyre circulation to cross-bank meandering type flows. From an initial qualitative analysis of atmospheric data, it was found that the frequency of the meandering type flows coincided with the passage of storm systems during the winter months, when the wind speed was the largest. The strength of the gyre circulation exhibits an annual cycle, with increased circulation during summer when storm activity is reduced and a decrease during the winter months when meandering type flows predominate (Anderson, 1992). The stability of the gyre circulation effectively determines the residence time of the water mass overlying the Cap. The time scale for a complete circulation of a parcel of water around the Cap (recirculation time) was found to be not generally equivalent to residence times of the water mass over the Cap. The available data suggest that residence times can be significantly less than re-circulation times. For example, Loder et al. (1988) using drifting buoy data calculated mean re-circulation times of 6778 days along the $400 \mathrm{~m}$ isobath with residence times of about 32 days. Akenhead (1986) calculated an exchange coefficient of Flemish Cap water of 0.025 per day ( $\approx 40$ days) using salinity budget calculations based solely on exchange with the Labrador Current water. The results of these studies led Loder et al. (1988) to conclude that based on a very limited data set, the gyre is intermittent and may be of limited significance to the overall circulation on the Cap. Nevertheless, the feature is not uncommon and most likely extends the residence times of Flemish Cap water, particularly during spring and summer months.

\section{Geostrophic Estimates}

The anticyclonic rotation of the water mass around the Flemish Cap was described by Kudlo and Burmakin (1972), Kudlo and Borovkov (MS 1975) and Kudlo et al. (1984) using geostrophic currents calculated from temperature and salinity measurements. To estimate the magnitude of interannual variations in the strength of the anticyclonic circulation around the Cap, we calculated the geostrophic circulation across the Cap along the $47^{\circ} \mathrm{N}$ line based on near-synoptic mid-July to mid-August $\mathrm{T} / \mathrm{S}$ data collected from 1950 to 1997 . The temperature and salinity data along the transect were averaged into $5 \mathrm{~km}$ horizontal by $5 \mathrm{~m}$ vertical bins, smoothed and then used to calculate the steric height for each horizontal bin. The geostrophic velocity was then computed from the horizontal gradient of the steric 
height using the geostrophic balance relationship according to Gill (1982).

Typical estimated geostrophic currents perpendicular to the $47^{\circ} \mathrm{N}$ transect (Fig. 3) based on T/S data collected during the summer of 1968 shows a particularly well formed anticyclonic component of the circulation around the Cap. These estimates, which are referenced to $300 \mathrm{~m}$, or to the bottom, in water depths less than $300 \mathrm{~m}$, show the well-known features of the circulation. The strong baroclinic component of the offshore branch of the Labrador Current to the west of the Cap in the Flemish Pass region, the general anticyclonic circulation around the Cap and the northward flowing water of the North Atlantic Current east of the Cap are all evident. Typical geostrophic speeds range from 5 to $10 \mathrm{~cm} / \mathrm{sec}$ in the gyre over the Cap and near $20 \mathrm{~cm} / \mathrm{sec}$ to the east of the Cap in the North Atlantic Current. While these speeds are not inconsistent with observations it is noted that near bottom currents may exceed $5 \mathrm{~cm} / \mathrm{sec}$ based on available current meter data, which will affect the geostrophic estimates.

The geostrophic transport was calculated by vertically integrating the velocity field within the $5 \mathrm{~km}$ grid cells and horizontally from the center of the Cap, both east and west for $150 \mathrm{~km}$. The total northward transport on the western side of the Cap and the southward transport on the eastern side were computed for each year and provided an estimate of the strength of the north-south component of the gyre circulation around the Cap. The results show a high degree of interannual variability due, in part, to shifts in the circulation features within the $150 \mathrm{~km}$ sections and also, most likely due to variations in the current strength itself (Fig. 4). Maximum transports ranged from 0.3 to $0.4 \mathrm{~Sv}\left(1 \mathrm{~Sv}=1.0 \times 10^{6} \mathrm{~m}^{3} / \mathrm{sec}\right)$ with minimum values near zero. The three year trend showed a consistent transport to the south on the offshore (eastern) portion of the Cap, of the order of $0.2 \mathrm{~Sv}$, and a somewhat weaker northward transport on the western (Flemish Pass) side of the Cap of the order of $0.1 \mathrm{~Sv}$ (Fig. 4). These estimates are consistent with anticyclonic rotation around the Cap during midsummer, however, variations are significant and in some cases a reverse flow is present on the western side of the Cap. This may indicate that variations in the Gulf Stream and the North Atlantic Current, particularly since the early-1980s, might play a role in the stability of the gyre. The limitations of the available data preclude a detailed examination of

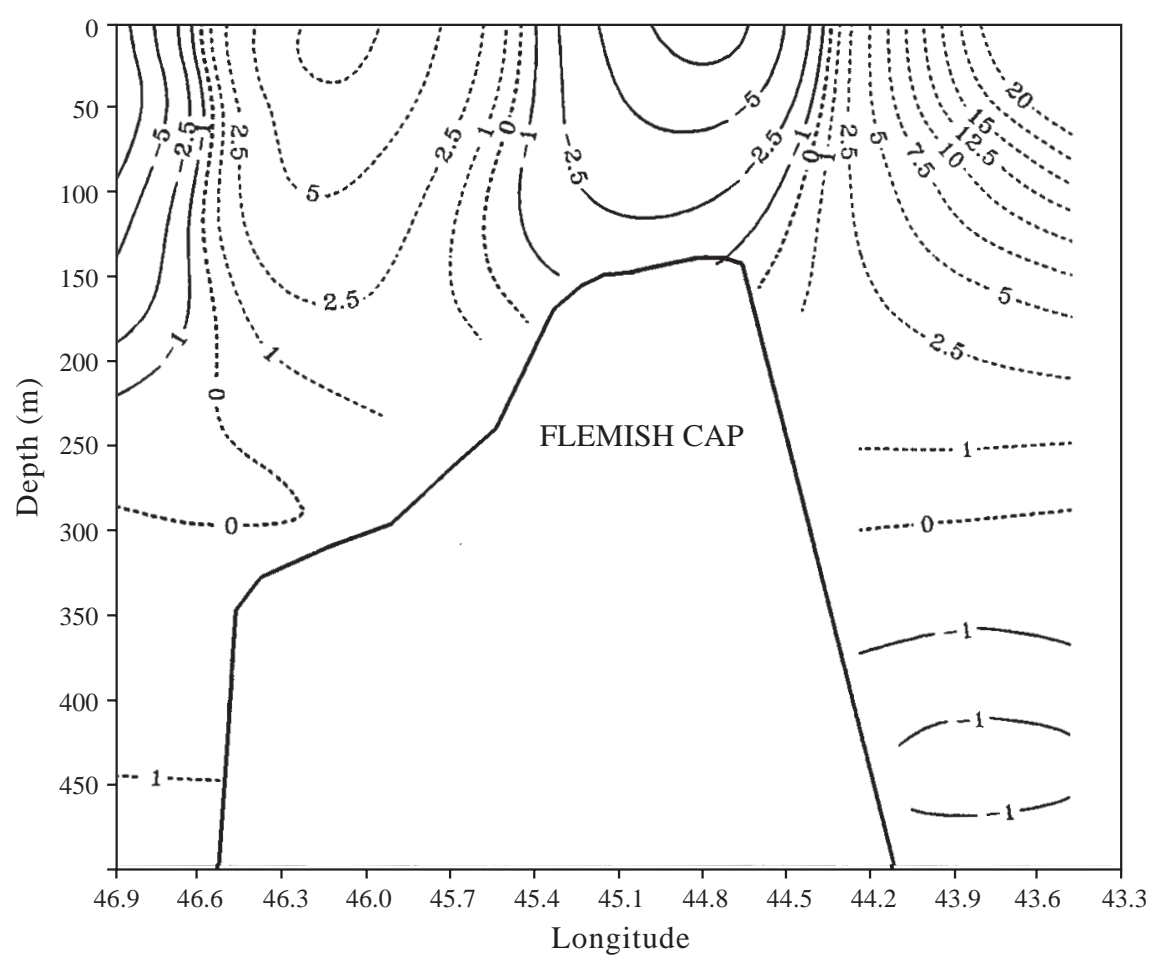

Fig. 3. The vertical distribution of the $\mathrm{N}-\mathrm{S}$ geostrophic current $(\mathrm{cm} / \mathrm{sec})$ field over the Flemish Cap during July of 1968. Negative currents (solid lines) are southward. 


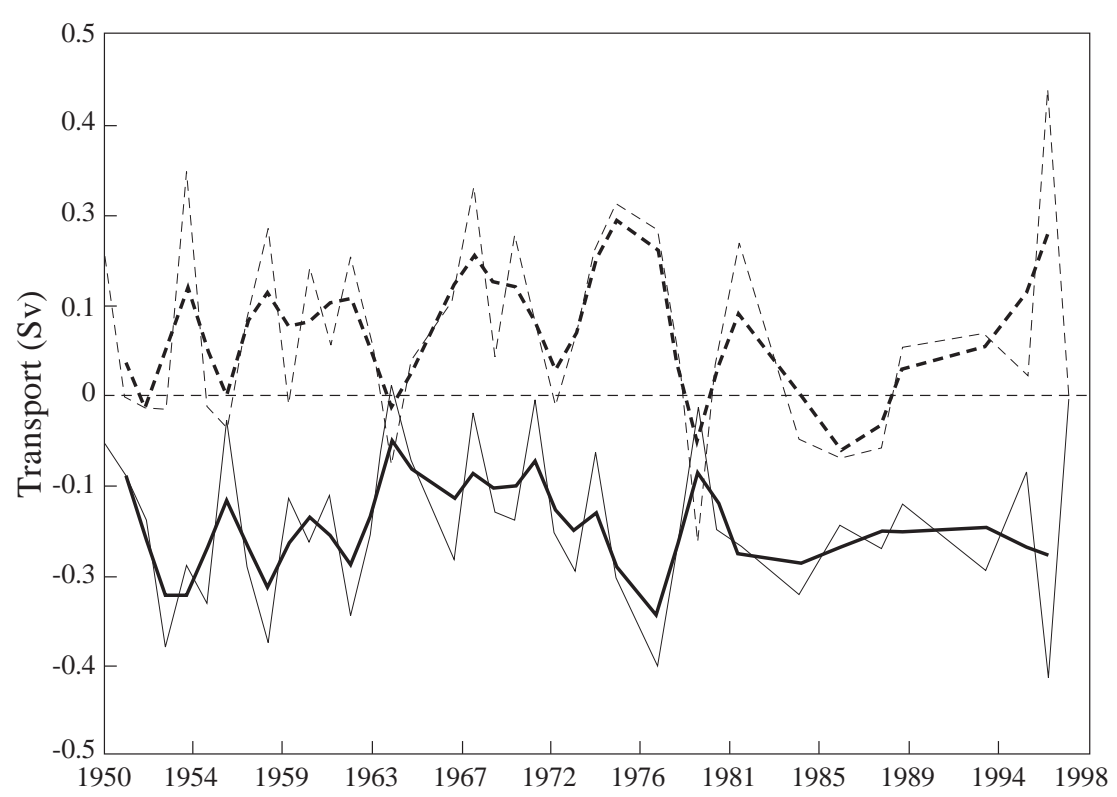

Fig. 4. Time series of summer geostrophic transport (Sv) through the $47^{\circ} \mathrm{N}$ transect across the Flemish Cap. The dashed lines are the northward transport on the western side of the Cap and the solid lines are the southward transport on the eastern portion of the Cap. To highlight the interannual trends, a 3-year running mean (heavy line) was applied to the time series.

long-term trends in the stability of the gyre on an annual basis. In the absence of more seasonal data, a more extensive examination of the geostrophic wind speed over the Cap similar to the analysis of Kudlo et al. (1984) may provide a better indication of trends in the stability of the circulation. No doubt, variations in the Labrador Current, the Gulf Stream and the North Atlantic Current all play important roles in the circulation around the Flemish Cap.

\section{Acoustic Doppler Current Observations}

Since 1993 currents on the Flemish Cap have been measured during mid-summer with hull-mounted 150 $\mathrm{kHz}$, RDI acoustic Doppler current profilers (ADCPs) at a spatial resolution of $4 \mathrm{~m}$ vertically by approximately $1.5 \mathrm{~km}$ horizontally. During this time period a total of 8 ADCP surveys were carried out across the Flemish Cap. The measurements were restricted to water depths less than $500 \mathrm{~m}$ where bottom referencing was possible. The useful depth range of the $150 \mathrm{kHz}$ ADCP for current measurements in this area was about $300 \mathrm{~m}$. More detailed information on ADCP data collection and subsequent analysis is presented by Colbourne et al. (1993).

The surveys showed a detailed view of the currents along the $47^{\circ} \mathrm{N}$ line across the center of the Cap (Fig. $5)$. In the Flemish Pass on the western side of the
Cap, the offshore edge of the Labrador Current flow in a southerly along-shelf direction with speeds generally greater than $10 \mathrm{~cm} / \mathrm{sec}$. Over the Flemish Cap itself, the circulation was predominately anticyclonic with northward currents of $5-15 \mathrm{~cm} / \mathrm{sec}$ over the western portion of the Cap and southward currents of $5-15 \mathrm{~cm} / \mathrm{sec}$ over the eastern portion. These data suggest re-circulation times of roughly 10 weeks along the $500 \mathrm{~m}$ isobath (assuming gyre width of approximately $200 \mathrm{~km}$ ) at an average current speed of about $10 \mathrm{~cm} / \mathrm{sec}$. Further up on the Cap, within the $200 \mathrm{~m}$ isobath, re-circulation times were of the order of 50 days at $10 \mathrm{~cm} / \mathrm{sec}$.

Consistent with the geostrophic calculations, ADCP surveys since 1993 showed considerable variability in both circulation patterns and current speeds. In July 1996 for example, the upper layer (10$50 \mathrm{~m}$ ) currents exhibited anticyclonic rotation, but the southward flowing current extended over most of the central portion of the Cap and speeds were in excess of $30 \mathrm{~cm} / \mathrm{sec}$ (Fig. 6), much stronger than typical tidal currents. These data also show the offshore branch of the Labrador Current on the Grand Bank side with speeds over $40 \mathrm{~cm} / \mathrm{sec}$. Unfortunately, observations in the deeper water of the Flemish Pass are not available. It is noted here that the ADCP data presented shows the total current field, which includes 


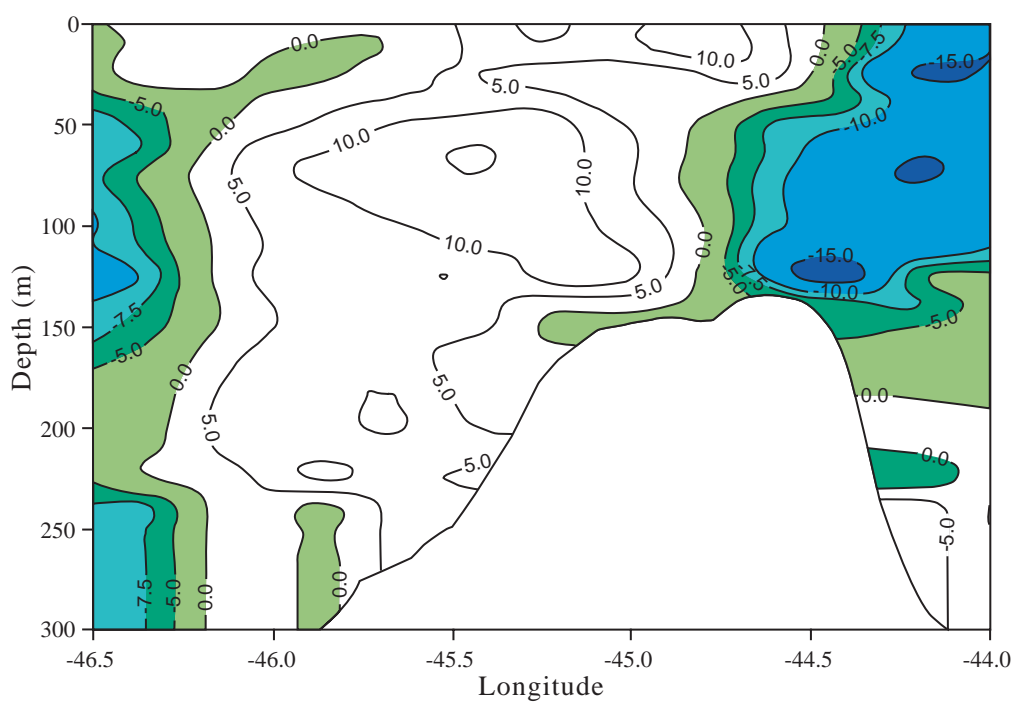

Fig. 5. A vertical cross-section of the north-south current field $(\mathrm{cm} / \mathrm{sec})$ over the Flemish Cap along $47^{\circ} \mathrm{N}$ during July of 1993 , measured with a ship mounted acoustic Doppler current profiler (ADCP). Negative currents (coloured) are southward, positive currents are northward.

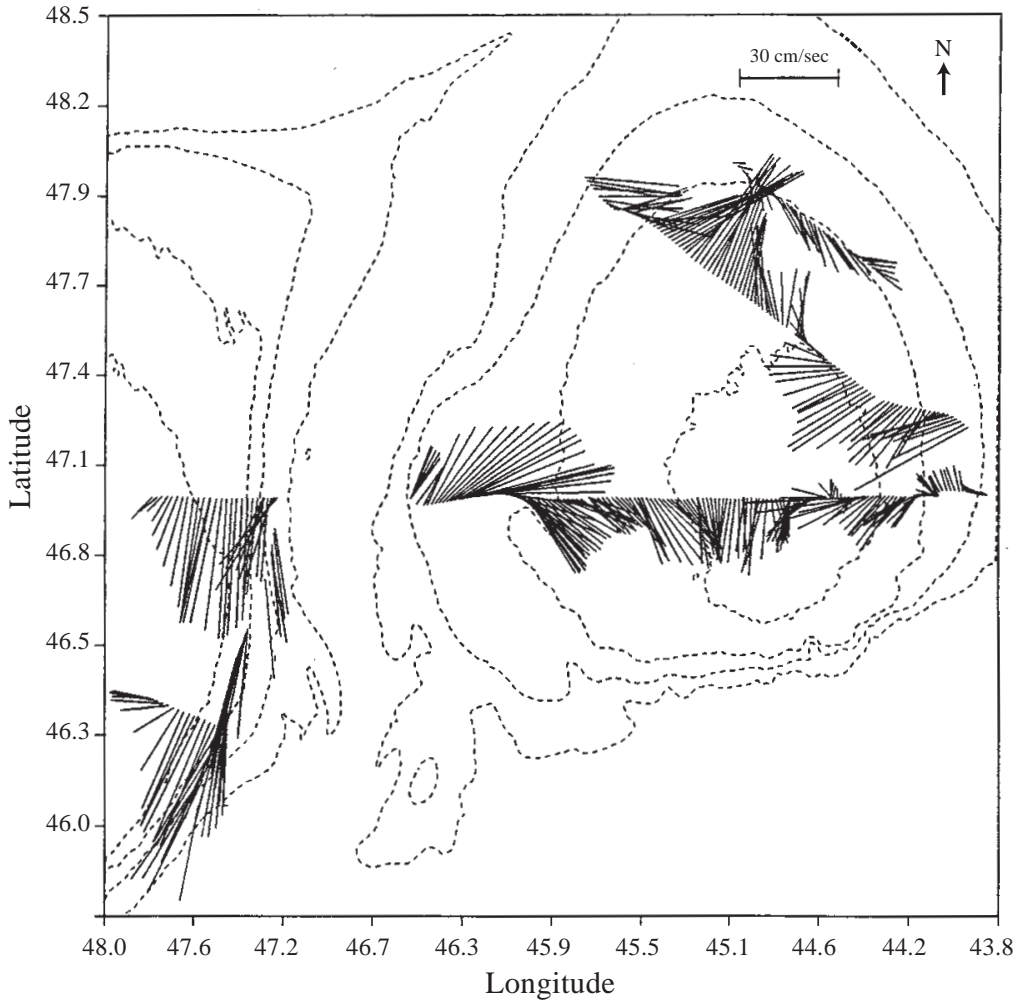

Fig. 6. The upper layer (10-50 m) circulation around the Flemish Cap and adjacent Grand Bank during July of 1996, measured with a ship mounted acoustic Doppler current profiler (ADCP). 
high frequency components such as wind driven flows, inertia currents and tides. Nevertheless, the general circulation around the Cap appears to be predominately anticyclonic in all surveys with typical recirculation times ranging from 50 to 70 days. In summary, both the directly measured currents and the geostrophic estimates show considerable variability between different years. For example, the 1997 geostrophic currents indicated a much weaker anticyclonic gyre than the 1996 data (Fig. 4). The geostrophic results also differred substantially, in some cases, from the direct current measurements made with the ADCPs, indicating the potential importance of bottom currents, wind driven flows and tidal currents on the Flemish Cap. Thus, although there are differences in the details of the circulation estimated by geostrophic calculations and acoustic profilers, both are consistent with the earlier work of the late-1970s and early-1980s in that they all show considerable variability about a generally sluggish anticyclonic circulation.

\section{Temperature and Salinity Variability Annual Cycles}

On the Flemish Cap the upper layer water column is nearly isothermal at a temperature between 3.5 to $4^{\circ} \mathrm{C}$ from late-January until April and remains at about 3.5 to $4{ }^{\circ} \mathrm{C}$ throughout the year at depths below approximately $75 \mathrm{~m}$. The phase of the seasonal temperature cycle is spatially coherent with the Newfoundland Shelf with warming in the upper layer commencing in early May and continuing to warm until late August to early September at a rate of about $0.1^{\circ} \mathrm{C}$ per day. Maximum surface temperatures reach about 12 to $13^{\circ} \mathrm{C}$, on average (Fig. 7a). Flemish Cap salinities tend to be uniform throughout the year with depth except in the upper-layer, which experience a gradual freshening from its February maximum, reaching a minimum of less than 33.2 by late-summer. At depths greater than $80 \mathrm{~m}$, salinities remain at about 34 to 34.5 over the entire year. While the amplitude of the salinity cycle on the Cap is somewhat less than on the Newfoundland Shelf, there is a significant upper layer salinity minimum on the Cap that extends from earlyAugust until early-December (Fig. 7b).

The strongest seasonal cycle in the water properties occurs in the upper layers, where storm forced mixing and exposure to the annual solar flux cycle is most intense. The seasonal cycle of continental shelf waters in the Northwest Atlantic consist of components at several frequencies due to the solar flux cycle, mixing rates, seasonal changes in stratification, freshwater runoff and ice formation and melting. In general, Petrie et al. (1991) showed that while the temperature phase is nearly uniform across the shelf due to the large-scale coherent solar heat input, the salinity phase shows significant spatial variability. This was attributed to the north-south advection of the Labrador Current and variations in ice production and melting on the shelf. In this analysis we fitted the seasonal cycle to Flemish Cap T/S data using harmonic analysis with components at periods of 1 , $1 / 2$ and $1 / 3$ years. The seasonal (all frequencies) surface temperature cycle ranged from a minimum of $3^{\circ} \mathrm{C}$ in February to $13^{\circ} \mathrm{C}$ in August with a mean of $7.4^{\circ} \mathrm{C}$ (Fig 8 ). The amplitude of the seasonal surface salinity cycle ranged from a maximum of near 34 in March to a minimum of about 33 in October with a mean of 33.5 (Fig. 8).

Amplitude and phase diagrams and tables of the annual and semi-annual components of the seasonal temperature and salinity cycle are displayed in Fig. $9 \mathrm{a}$ and $\mathrm{b}$, and Tables 1 and 2 . The contribution of the $1 / 3$ - year harmonic accounted for less than $10 \%$ of the total signal. The amplitude and phase of the annual component of the surface seasonal temperature cycle over the Cap is $4.5^{\circ} \mathrm{C}$ compared to $6.9^{\circ} \mathrm{C}$ on the Newfoundland Shelf at Station 27, while the phase at both locations was about 243 days. The amplitude of the annual component of the temperature cycle decreased to less than $1^{\circ} \mathrm{C}$ at $100 \mathrm{~m}$ depth and was not significant below that. The phase was near uniform in the upper $40 \mathrm{~m}$ of the water column but increased to day 337 at $100 \mathrm{~m}$ depth (Fig. 9a). The amplitude and phase of the semi-annual component of the temperature cycle decreased from approximately $1{ }^{\circ} \mathrm{C}$ at the surface to $0.2^{\circ} \mathrm{C}$ at $100 \mathrm{~m}$ depth, while its phase increased from day 37 to over 375 at $100 \mathrm{~m}$ depth.

The amplitude and phase of the annual component of the surface salinity cycle was about 0.45 and 90 days respectively, compared to 0.66 (89 days) at Station 27 (Petrie et al., 1991; and Colbourne and Fitzpatrick, 1994). The amplitude decreased to approximately 0.1 at $100 \mathrm{~m}$ depth and the phase increased to day 270 . The amplitude and phase of the semi-annual component of the salinity cycle ranged from 0.14 at $30 \mathrm{~m}$ depth to 0.02 at $100 \mathrm{~m}$, while its phase increased from day 20 at the surface to day 85 at $100 \mathrm{~m}$ depth (Fig. 9b). 

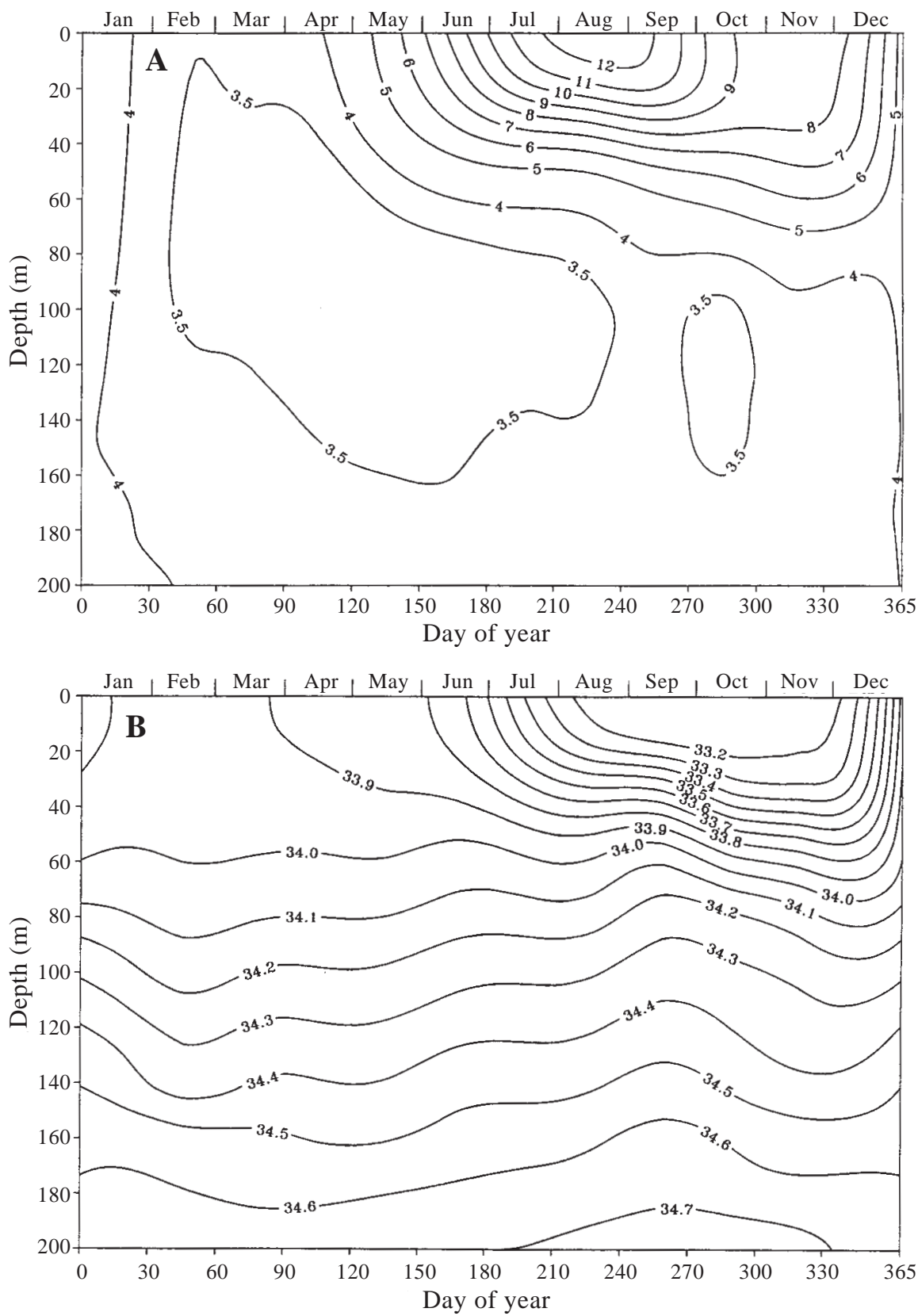

Fig. 7. The month mean (A) temperature and (B) salinity over the central Flemish Cap (area FC in Fig. 1) based on all available historical data from 1961 to 1990.

While the amplitudes of both the temperature and salinity annual and semi-annual components of the seasonal cycles were smaller than those observed at Station 27 on the inner Newfoundland Shelf, the vertical structure of both the amplitudes and phases were very similar. In addition, the time required for heat to penetrate to $100 \mathrm{~m}$ depth on both the Flemish Cap and at Station 27 was identical at 100 days. These results based on the 1961-90 data set are very similar to those obtained by Petrie et al. (1991) who used data complied by Drinkwater and Trites (1986) from 191082 on the central Flemish Cap. There are however differences in the salinity cycle on the Cap compared to the Newfoundland Shelf below the surface layer. The freshening at Station 27 propagates deeper into the water column beginning in late spring, reaching below $125 \mathrm{~m}$ by late autumn as a result of upstream mixing on the continental shelf. The Flemish Cap is 

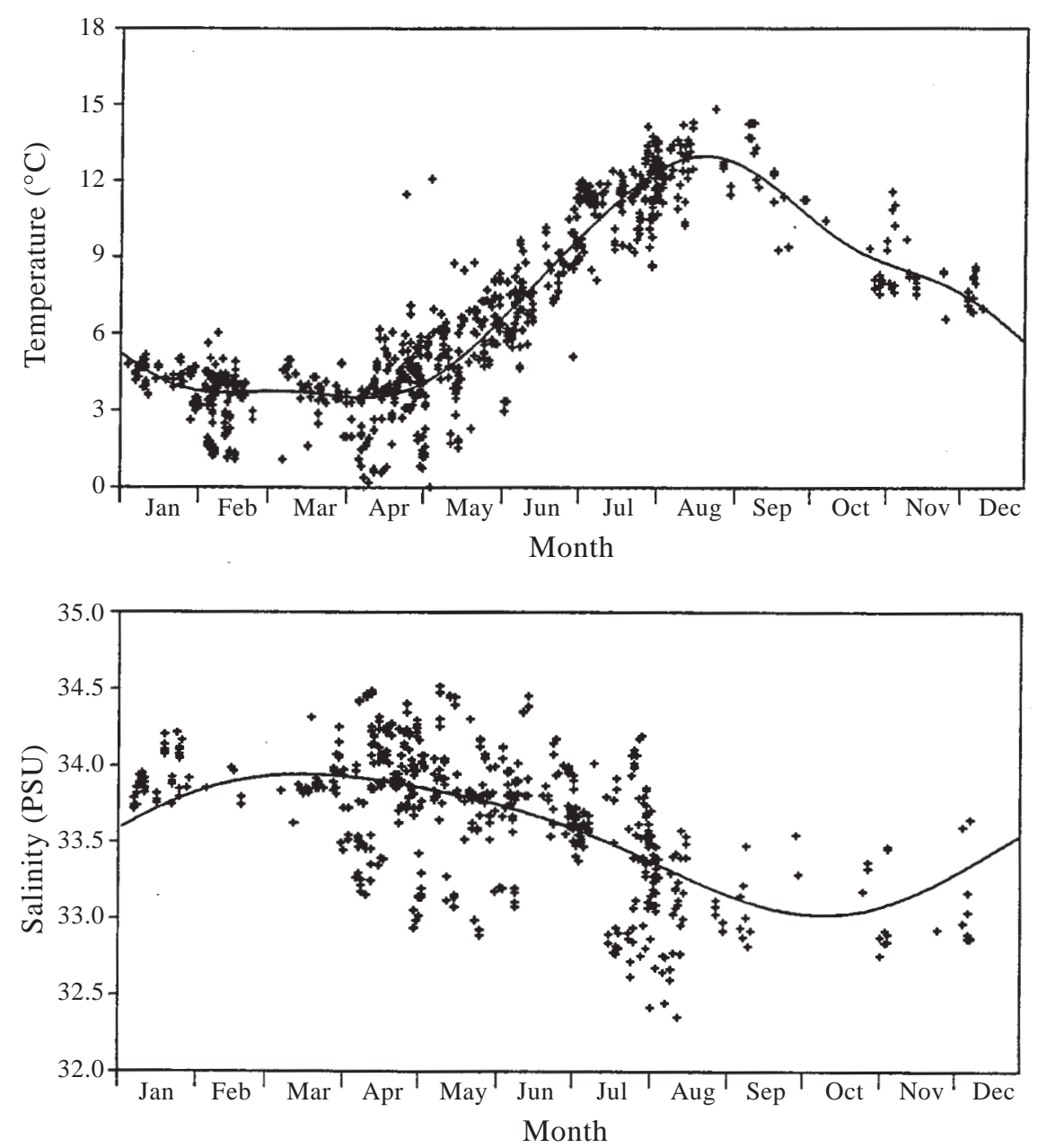

Fig. 8. The Flemish Cap (area FC, Fig. 1) seasonal surface temperature and salinity distributions. The solid lines are the fitted least-squares regressions to the seasonal cycle.

somewhat isolated from the freshening effects of the coastal continental shelf ice melt and hence displays a smaller salinity range compared with the adjacent Grand Banks.

\section{Interannual Variability}

Time series of temperature and salinity anomalies for the area shown in Fig. 1 on the Flemish Cap were constructed by standard techniques, whereby a least squares fit (Fig. 8) to the seasonal cycle was subtracted from each observation and then averaged by month. The anomalies were referenced to the 1961-90 standard base period and computed for several standard depths between 1950-98. To highlight longterm trends the monthly anomalies were low-pass filtered by applying a simple running mean to the data. Discussions on the calculation of anomalies from large spatial areas and their limitations are found in Colbourne et al. (1994) and Drinkwater et al. (1996).

The low-frequency temperature structure was characterized by fluctuations ranging from about $\pm 2^{\circ} \mathrm{C}$ in amplitude at time scales ranging from one year to near decadal. Superimposed on this were large amplitude monthly variations, due in part, to high frequency changes in the water properties, but also as a result of spatial variation at constant depth within the selected area and possibly due to variations in the number of observations available within a particular month. The amplitude of the temperature anomalies tended to decrease with increasing water depth suggesting surface forcing. The time series was characterized by 3 major cold periods: most of the 1970s, the mid-1980s and the late-1980s to early- 


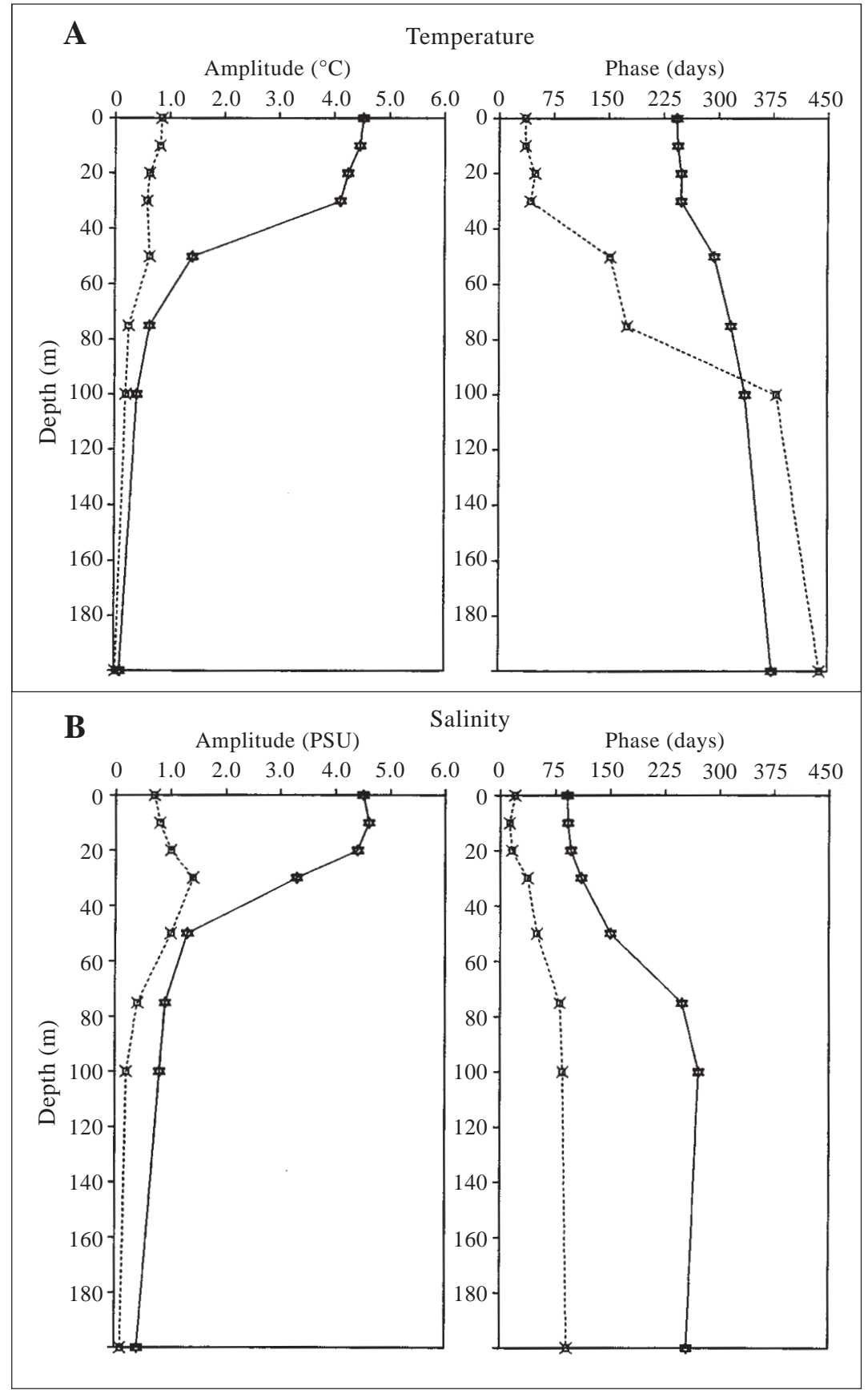

Fig. 9. Vertical profiles of the amplitude and phase (computed from the coefficients of the least-squares fit to the seasonal cycle) of the annual (solid lines) and the semi-annual (dashed lines) components of the seasonal (A) temperature cycle and (B) salinity cycle for area FC of Fig. 1 on the Flemish Cap.

1990s. Prior to the early-1970s the anomalies for the most part were either near normal or above normal. During the cold period of 1971 to 1977 temperature anomalies reached values of near $2^{\circ} \mathrm{C}$ below normal over the upper water column. From 1978 to 1984, the temperature anomalies showed a high degree of variability in the upper water column with a tendency towards positive anomalies. By 1985, intense negative temperature anomalies had returned with peak amplitudes reaching between 2 to $3^{\circ} \mathrm{C}$ below normal in the top $50 \mathrm{~m}$ of the water column. This cold period moderated briefly in 1987 and 1988 but the 
TABLE 1. The amplitudes $\left(a_{1}\right)$ and phases $\left(\phi_{1}\right)$ of the annual and semi-annual components of the leastsquares fit to the seasonal temperature cycle on the Flemish Cap at standard water depths. The means $\left(a_{0}\right)$ are also listed. The phase is defined relative to 1 January.

\begin{tabular}{cccccc}
\hline \hline Depth $(\mathrm{m})$ & $a_{1}\left({ }^{\circ} \mathrm{C}\right)$ & $\phi_{1}$ (days) & $a_{2}\left({ }^{\circ} \mathrm{C}\right)$ & $\phi_{2}($ days $)$ & $a_{0}\left({ }^{\circ} \mathrm{C}\right)$ \\
\hline & & & & & \\
0 & 4.52 & 243 & 0.85 & 36 & 7.41 \\
10 & 4.46 & 244 & 0.82 & 36 & 7.34 \\
20 & 4.24 & 249 & 0.63 & 49 & 7.11 \\
30 & 4.11 & 249 & 0.58 & 43 & 7.04 \\
50 & 1.41 & 294 & 0.63 & 152 & 4.75 \\
75 & 0.63 & 317 & 0.25 & 175 & 3.84 \\
100 & 0.40 & 337 & 0.20 & 15 & 3.52 \\
200 & 0.10 & 8 & 0.02 & 74 & 3.87 \\
\hline
\end{tabular}

TABLE 2. The amplitudes $\left(a_{1}\right)$ and phases $\left(\phi_{1}\right)$ of the annual and semi-annual components of the leastsquares fit to the seasonal salinity cycle on the Flemish Cap at standard water depths. The means $\left(a_{0}\right)$ are also listed. The phase is defined relative to 1 January.

\begin{tabular}{cccccc}
\hline \hline Depth $(\mathrm{m})$ & $a_{1}\left({ }^{\circ} \mathrm{C}\right)$ & $\phi_{1}($ days $)$ & $a_{2}\left({ }^{\circ} \mathrm{C}\right)$ & $\phi_{2}($ days $)$ & $a_{0}\left({ }^{\circ} \mathrm{C}\right)$ \\
\hline 0 & 0.45 & 91 & 0.07 & 20 & 33.53 \\
10 & 0.46 & 92 & 0.08 & 13 & 33.53 \\
20 & 0.44 & 96 & 0.10 & 16 & 33.56 \\
30 & 0.33 & 110 & 0.14 & 37 & 33.66 \\
50 & 0.13 & 150 & 0.10 & 50 & 33.89 \\
75 & 0.09 & 248 & 0.04 & 81 & 34.10 \\
100 & 0.08 & 271 & 0.02 & 85 & 34.27 \\
200 & 0.04 & 255 & 0.01 & 91 & 34.69 \\
\hline
\end{tabular}

temperatures fell below normal again by 1989 and continued to drop until they reached a minimum of $3^{\circ} \mathrm{C}$ below normal by the summer of 1993 . The most recent cold period continued until 1996 when temperatures began to warm to above normal values, which continued into 1999 (Fig. 10a).

Prior to the early-1970s salinity anomalies for the most part were either near normal or above normal. The salinity time series showed fresher-than-normal conditions from 1971 to 1975 , corresponding to the "Great Salinity Anomaly" (Dickson et al., 1988). From 1983 to 1986 salinities were again below normal with peak amplitudes reaching 0.6. Salinities during the early-1990s were only slightly below normal, thus indicating differences between the anomalous periods. Since about 1995 they returned to normal conditions, which continued, into 1999 (Fig. 10b). Insufficient data were available in the deeper waters around the Cap to construct reliable time series of salinity anomalies. The salinity anomaly during the early1990s on the Flemish Cap was much weaker than that of the mid-1980s and early-1970s and also much weaker than that of the early-1990s on the Newfoundland Shelf (Fig. 11a). The large magnitude of the anomaly during the early-1970s on the Cap was a result of the larger scale salinity anomaly referred to above. In general, the amplitude of both the temperature and salinity anomalies were maximum in the upper water column where the influence of variations in the atmosphere-ocean heat flux and continental shelf ice conditions were the largest.

The vertically averaged temperature and salinity anomaly time series on the Flemish Cap and at Station 27 shows large amplitude fluctuations, at near decadal time scales, with cold periods during the early-1970s, mid-1980s and early-1990s (Fig. 11b). During the time period from 1950 to the late-1960s the heat content of the water column was generally above the long-term mean. During 1996 it recovered to a near record high from the near record lows of 1991 and continued at or above the long-term means in both 1997 and 1998. The salinity anomalies showed similar behaviour as the heat 
content time series with fresher than normal periods corresponding to the colder than normal conditions. The magnitude of the low salinity anomaly on the inner Newfoundland Shelf at Station 27 during the early1990s was comparable to that experienced during the 'Great Salinity Anomaly' of the early-1970s. The salinity anomaly on the Flemish Cap during this period was of a lower magnitude than that experienced on the Newfoundland Shelf, possibly indicating differences in the advection patterns between the two periods.

\section{Air-Sea Heat Flux Variability}

\section{Annual Cycles}

The Comprehensive Ocean-Atmosphere Data Set (COADS) (available from the National Center for
Atmospheric Research (NCAR) of Boulder Colorado, USA) consisting of monthly averages of surface and meteorological observations within $1^{\circ}$ latitude by $1^{\circ}$ longitude squares were used to compute estimates of air-sea heat fluxes on the Flemish Cap. The net heat flux $(Q)$ assumed positive into the ocean was calculated as the sum of the short-wave radiative flux $\left(Q_{s}\right)$, the long-wave flux $\left(Q_{i}\right)$, the latent heat flux $\left(Q_{l}\right)$ and the sensible heat flux $\left(Q_{h}\right)$. Negative values represent a heat loss from the ocean. The components of the heat flux were computed using the methods and coefficients provided by Isemer and Hasse (1987) and Isemer et al. (1989). Standard deviations in the climatological monthly estimates were estimated in the $20-60 \mathrm{~W} \mathrm{~m}^{-2}$ range, with the higher values occurring during the winter months. Since sea ice

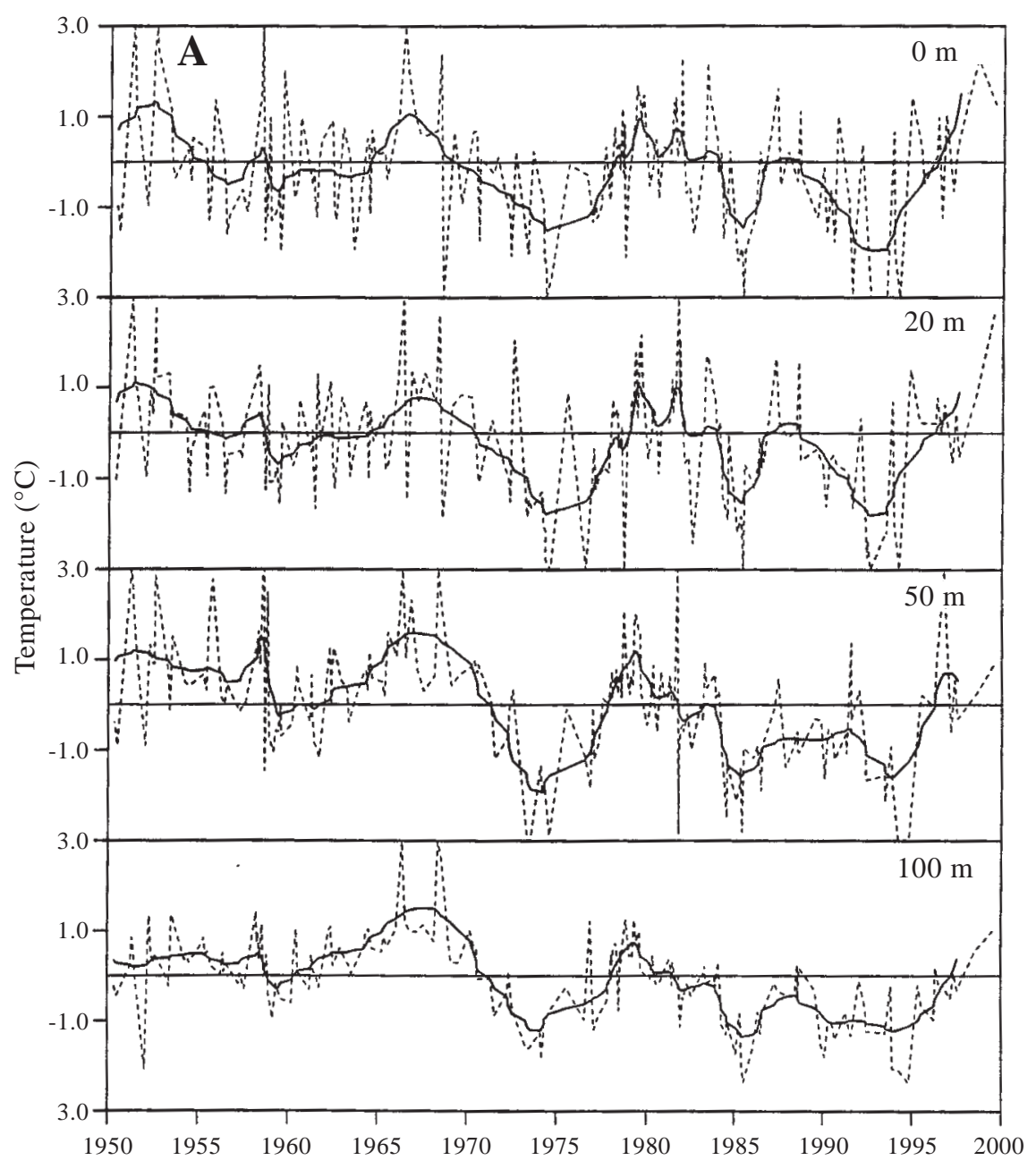

Fig. 10a. Time series of temperature anomalies on the Flemish Cap (area FC, Fig. 1) at standard depths. The dashed lines are monthly values and the heavy line represents the 5-year running means. 


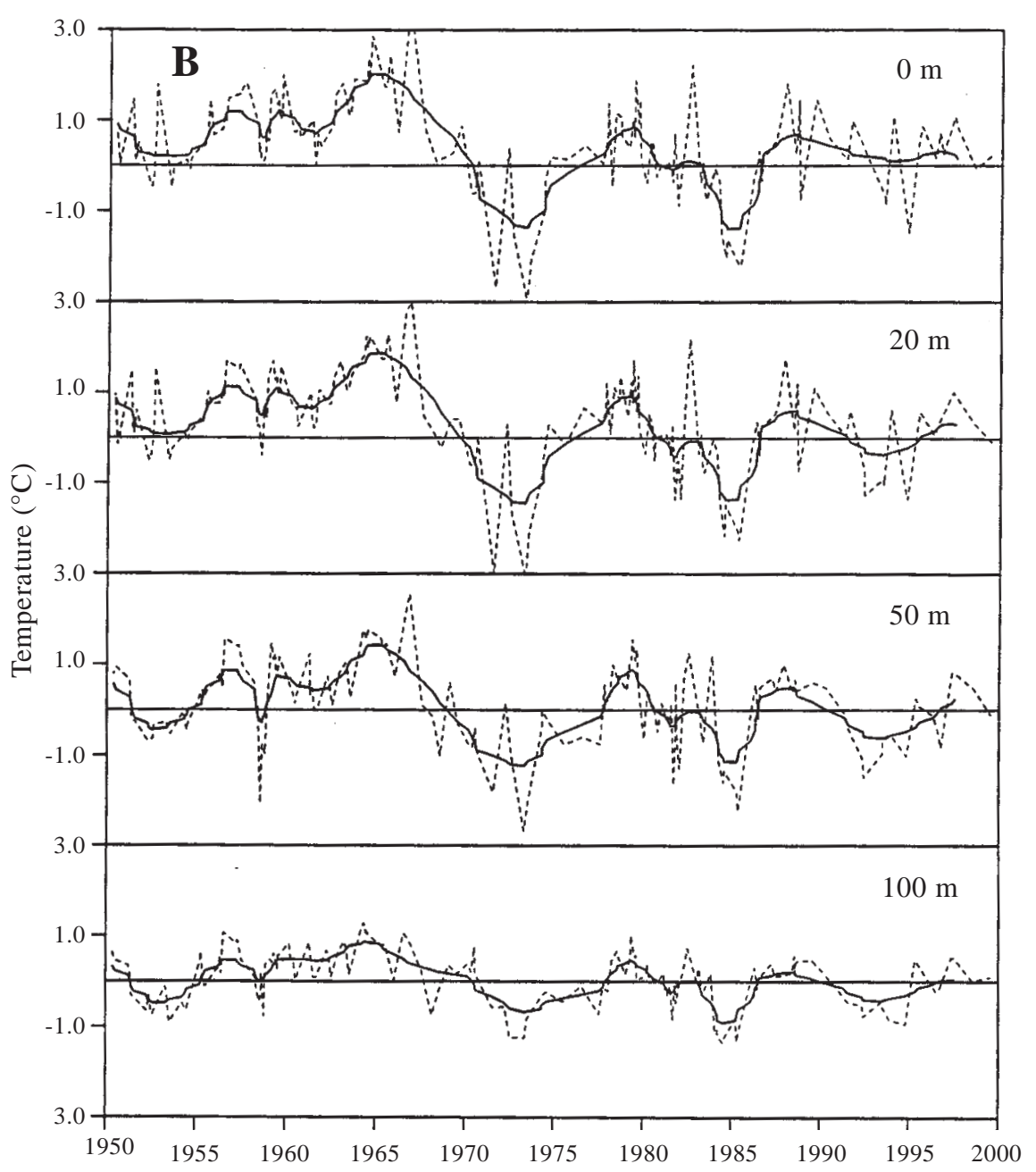

Fig. 10b. Time series of salinity anomalies on the Flemish Cap (area FC, Fig. 1) at standard depths. The dashed lines are monthly values and the heavy line represents the 5-year running means.

encroached on the Flemish Cap only briefly during the severest of ice years, it was ignored in these estimates. Each variable (sea surface and air temperature, wind speed, sea level pressure, cloudiness and humidity) necessary to compute the components of the heat flux was quality controlled by trimming the time series provided by NCAR using 2.5 standard deviations. If a monthly value of each variable exceeded this limit it was replaced by an average of the values for the adjacent months.

The atmosphere-ocean net heat flux exhibited a strong annual cycle, primarily driven by the shortwave solar flux, with a heat loss of the order of 100 $\mathrm{W} \mathrm{m}^{-2}$ during the winter to a heat gain of $190 \mathrm{~W} \mathrm{~m}^{-2}$ during summer. Averaged over the year, however, there was net heat input into the ocean over the Flemish Cap, of the order of approximately $35 \mathrm{~W} \mathrm{~m}^{-2}$ (Fig. 12a). During summer the water over the Flemish Cap gained heat through the sensible heat flux, while the long-wave and latent fluxes contributed to a mean heat loss throughout the year of 35 and $40 \mathrm{~W} \mathrm{~m}^{-2}$, respectively. Heat budget calculations for the adjacent Newfoundland Shelf also show that the atmosphere supplies more heat to the ocean than it extracts (Umoh et al., 1995), indicating the presence of an advective component to the overall heat budget.

Displayed in Fig. 12b are monthly values of the net air-sea heat flux and the time rate of change of the depth integrated heat content $(\partial H / \partial t)$ on the Flemish Cap. The data used to compute the heat 
content was compiled from all available temperature profiles within the area (FC) on the Cap defined in Fig 1. Monthly averaged temperature profiles were then constructed and depth integrated to produce monthly values of heat content. The time rate of change of the heat content of the water column exhibited a strong annual cycle with decreasing heat content of the order of $180 \mathrm{~W} \mathrm{~m}^{-2}$ during the winter months, to increasing heat content of approximately $200 \mathrm{~W} \mathrm{~m}^{-2}$ during spring and summer months. In
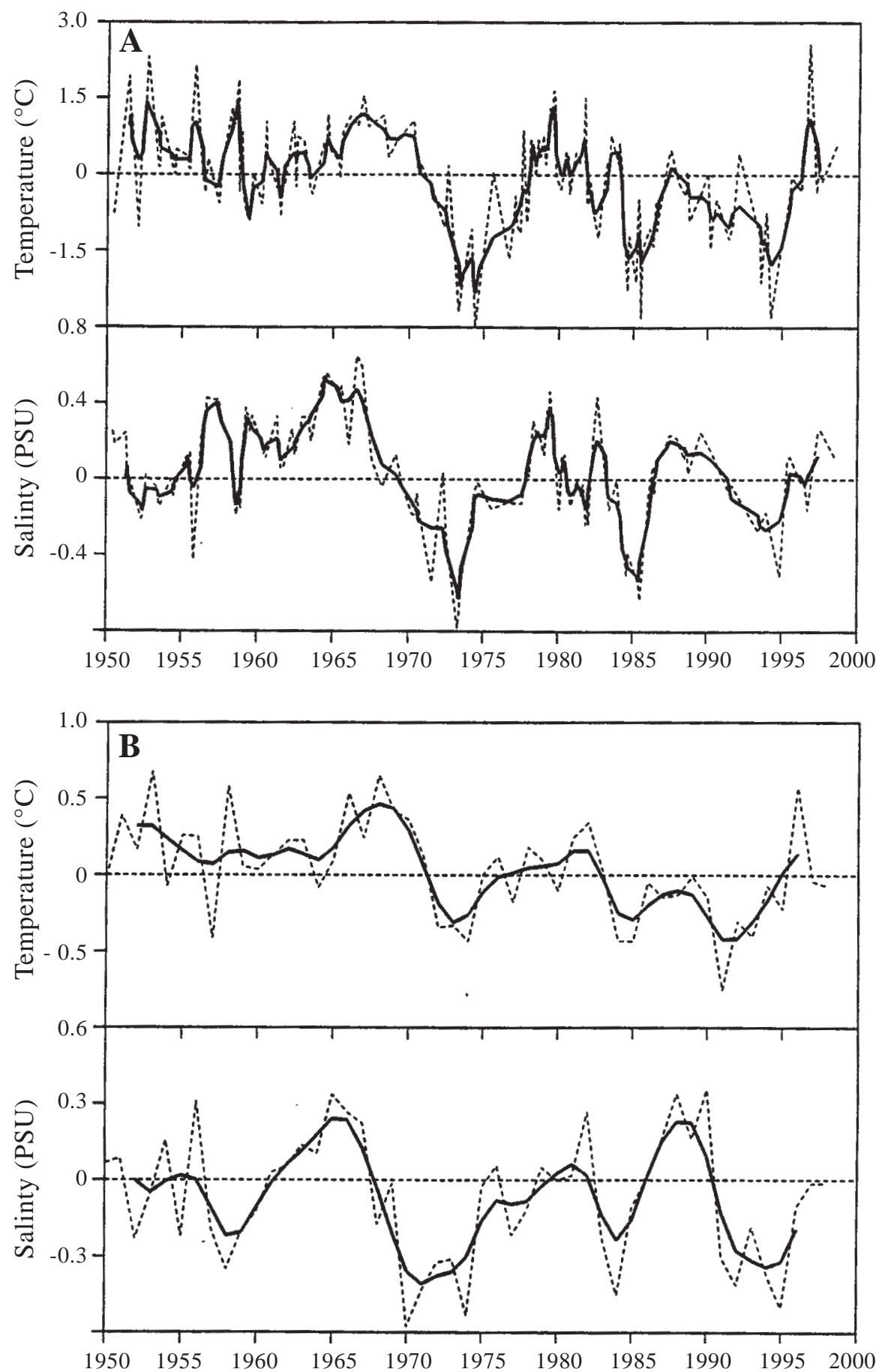

Fig. 11. Time series of (A) Flemish Cap vertically averaged $(0-150 \mathrm{~m})$ temperature and salinity, and (B) time series of Station 27 vertically averaged $(0-176 \mathrm{~m})$ temperature and salinity. 




Fig. 12. The climatological annual cycle of (A) the total solar heat flux $\left(Q_{S}\right)$, the out going infrared flux $\left(Q_{I}\right)$, the latent heat flux $\left(Q_{L}\right)$ the sensible heat flux $\left(Q_{H}\right)$ and the net air-sea heat flux $(Q)$ for area FC shown in Fig. 1 on the Flemish Cap, and (B) the climatological annual cycle of the net air-sea heat flux $(Q)$ (solid line) and the climatological annual rate of change of the depth-integrated $(0-150 \mathrm{~m})$ heat content (dashed line)) for area FC shown in Fig. 1 on the Flemish Cap. The error bars are \pm 1 standard deviation.

general, the surface net heat flux exceeded the rate of change of the water column heat content for all months except for February and May, however in some months the difference was not significant. The greatest difference occurred in February when the rate of change of heat content exceeded the heat input from the surface by approximately $100 \mathrm{~W} \mathrm{~m}^{-2}$. In the absence of other processes, the time rate of change of the water column heat content $(\partial H / \partial t)$ will be equivalent to the rate of net surface heat input $(Q)$. On the Flemish Cap the annual excess heat input (35 $\mathrm{W} \mathrm{m}^{-2}$ ) to the surface water was most likely dissipated by horizontal advection of colder water from the offshore branch of the Labrador Current. 


\section{Interannual Variability}

In order to access the interannual variability in the net, latent and sensible air-sea heat flux we computed anomalies by subtracting the 1961-90 climatological monthly averages from the monthly observations. The resulting anomaly time series was dominated by large monthly fluctuations exceeding $60 \mathrm{~W} \mathrm{~m}^{-2}$. The low frequency variability was dominated by fluctuations of approximately $20 \mathrm{~W} \mathrm{~m}^{-2}$ above and below the mean at time scales of approximately 4 to 8 years (Fig. 13). During the early1970 s and the late-1980s the net heat input to the surface water was below average, corresponding to the colder-than-normal water temperatures observed on the Flemish Cap. Similar conditions were also observed on the Newfoundland Shelf during the same time periods (Umoh et al., 1995). However during the early- to mid-1990s the net air-sea heat flux anomalies ranged from about normal to above normal, even though the upper layer temperatures on the Cap were well below the long-term average (Fig. 10a). This result indicates that advection is probably the primary mechanism determining variability in the water mass characteristics on the central Flemish Cap, particularly during the cold period of the early-1990s.

\section{Discussion and Summary}

Geostrophic calculations and ADCP current measurements presented show considerable variability in the circulation patterns over the Flemish Cap. However, the results are consistent with earlier work, all of which show a generally sluggish anticyclonic circulation, which frequently breaks down into meandering cross-bank flows, resulting in a finite residence time of the water mass on the Cap. Previous studies have indicated that residence times are approximately 30-40 days, roughly $1 / 2$ of recirculation times based on drifting buoy data. The time series of summer geostrophic transport show considerable variability about a persistent trend towards anticyclonic circulation. The average longterm trend of about $0.2 \mathrm{~Sv}$ on the eastern side of the Cap indicate a persistent influence of the offshore branch of the Labrador Current to the water mass circulation in the region. This feature seems to be more prevalent than the northward component of the circulation particularly during 1980s and early-1990s (Fig. 4). In addition, data from several ADCP surveys conducted during the 1990s all show evidence of some degree of gyre circulation. In summary, the gyre circulation around the Flemish Cap is a common

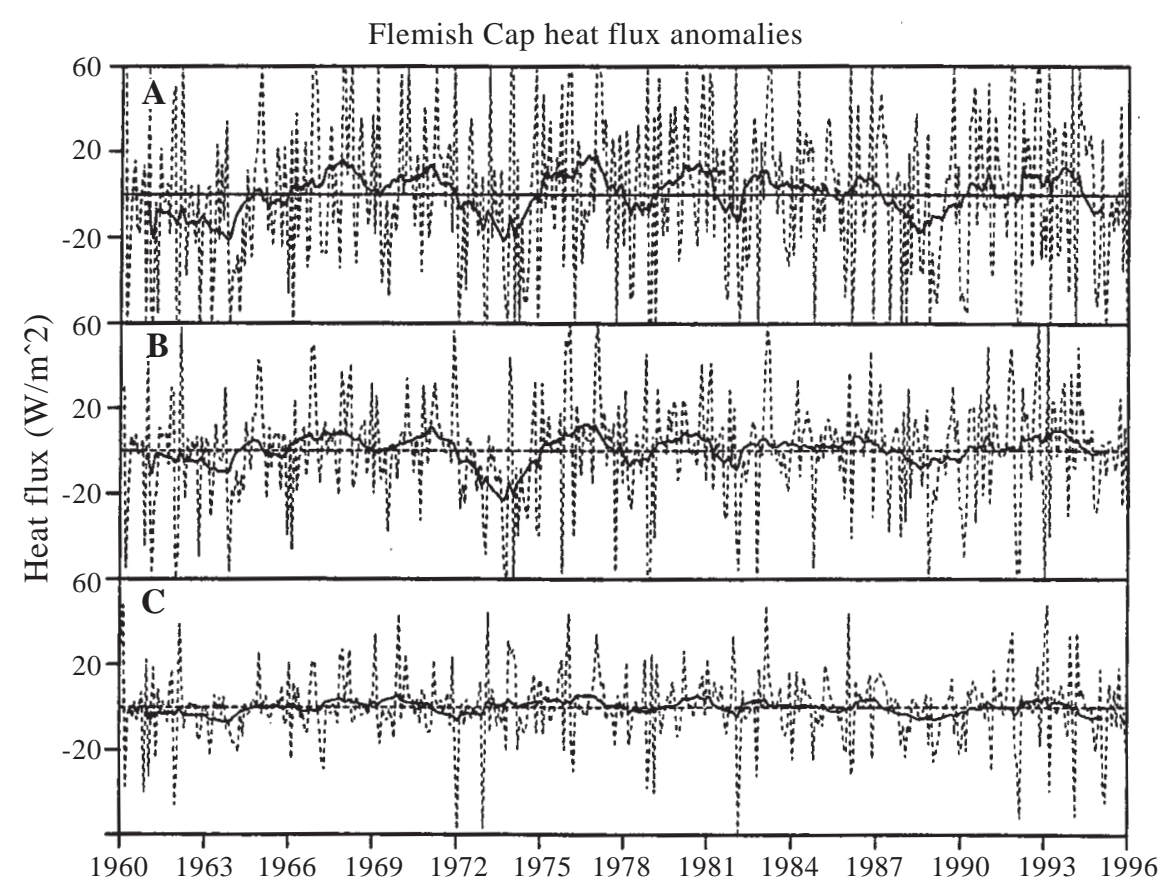

Fig. 13. Time series of monthly (dashed line) (A) net, (B) latent and (C) sensible, airsea heat flux anomalies over the Flemish Cap. The solid line represents the 5year running means. 
feature particularly during the summer months when wind forcing by passing storms is at a minimum. As a result it probably increases the residence time on the Cap of the water mass and hence of passive drifters such as pelagic fish eggs and larvae during those time periods.

The decrease in the amplitudes of both the temperature and salinity seasonal cycles compared to those on the inner Newfoundland Shelf indicate that the intensity of the freshening effects of continental shelf ice melt and coastal freshwater runoff is somewhat reduced on the Flemish Cap. Also as indicated in Fig. 7 the depth of heat penetration and freshening on the Flemish Cap is shallower than that on the inner Newfoundland Shelf. Pertie et al. (1991) attributed this to the autumn breakdown in the stratification and greater convective mixing near the continental landmass. However, the fact that the vertical structure of both the amplitudes and phases are very similar, at least in the upper $100 \mathrm{~m}$ of the water column indicates similar broad scale forcing mechanisms.

The trends in water mass properties over the Flemish Cap are very similar to those observed on the Newfoundland Continental Shelf. The vertically averaged T/S at Station 27 and on the Cap show a remarkable similarity (Fig. 11a and b). The correlation between the vertically averaged temperature and salinity at Station 27, which is located in the inshore branch of the Labrador Current and on the Flemish Cap is 0.67 and $0.58, p<0.05$, respectively (Fig. 11). Indeed, similar conditions existed over most areas of the continental shelves in the Northwest Atlantic during the same time period (Colbourne et al., 1994; Drinkwater 1996; Drinkwater et al., 1996). Studies have shown that these conditions are linked to the large-scale atmospheric forcing, winter and spring sea ice conditions and ocean advection. As shown in Fig. 14 the near decadal trends in the winter atmospheric circulation in the Northwest Atlantic (the NAO index, Rogers, 1984) are highly correlated with trends in temperature both at Station $27(r=-0.66, p<0.05)$ and on the Flemish Cap $(r=-0.67, p<0.05)$, indicating similar forcing mechanisms.

Umoh et al. (1995) indicated that about $77 \%$ to $89 \%$ of the variance in the annual temperature on the Newfoundland Shelf could be explained by the annual variations in the local air-sea heat flux. But given the large-scale coherence of the solar heat input the effects of advection could not be determined. Averaged throughout the year on the Flemish Cap the surface air-sea heat flux exceeds the rate of change of the water column heat content by approximately $35 \mathrm{~W} \mathrm{~m}^{-2}$. The correlation between the monthly average air-sea heat flux and the average rate of change of heat content of the water column on the cap is $0.86(p<0.05)$, indicating that approximately $74 \%$ of the variance in heat content of the water column on the Cap can possibly be explained by the net surface heat input. Again, however, because of the large-scale coherence of the annual variations in the air-sea heat flux, this result does not partition the effects of advection. In fact, a comparison of the time series of T/S anomalies (Fig. 11a) on the Cap with the local air-sea heat flux

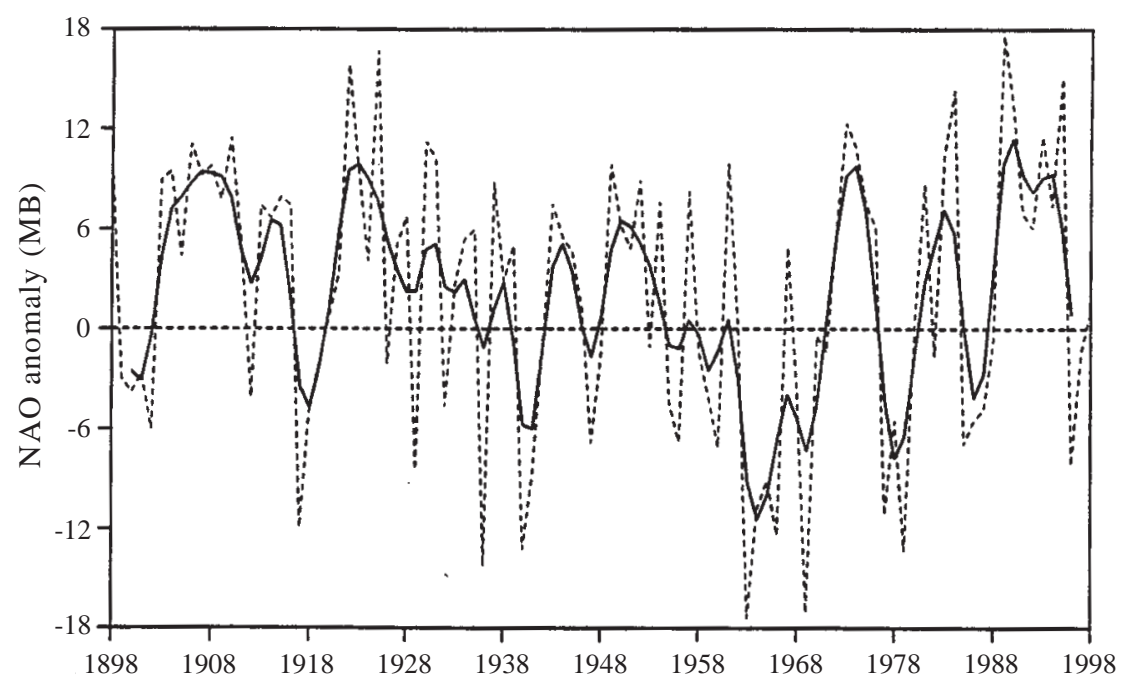

Fig. 14. Time series of yearly (dashed line) North Atlantic Oscillation Index (NAO) anomalies. The solid line represents the 5-year running means. 
anomalies (Fig. 13) together with Station $27 \mathrm{~T} / \mathrm{S}$ anomalies (Fig. 11b) indicate that probably more than $26 \%$ of the variance in the heat content is due to advection.

Finally, we note that the correlation between the low-passed filtered time series of local air-sea heat flux (Fig. 13) over the Cap and the upper layer $(\leq 100-\mathrm{m})$ temperature on the Cap (Fig. 11a) is not significant at $r=0.12(p=0.50)$. Therefore we conclude that the annual difference in the net air-sea heat flux and the time rate of change in the heat content of the water column over the Flemish Cap is most likely due to advection of cooler water from upstream over the Newfoundland and Labrador Shelf Slope regions. These waters, which are exposed to the large-scale meteorological conditions in the Northwest Atlantic, are advected onto the Flemish Cap by the offshore branch of the Labrador Current. This conclusion is consistent with Akenhead's (1986) result that the Labrador Current Slope water is the sole source of water within 100-m depth on the central Flemish Cap. His conclusion was reached using salinity budget calculations based solely on exchange with Labrador Current Slope water. Therefore the updated analysis we have presented on water property correlation, observed water mass circulation and local air-sea heat flux variability indicates the dominance of horizontal advection of Labrador Current water into the region as the principle cause of oceanic variability on the Flemish Cap.

\section{Acknowledgements}

We thank C. Fitzpatrick and P. Stead of the oceanography section of the Northwest Atlantic Fisheries Centre, Newfoundland, for providing technical support for oceanographic data acquisition during the many annual oceanographic surveys on the Flemish Cap and Newfoundland Shelf. We thank Dr. S. Narayanan and D. Parsons for many helpful comments and suggestions. We thank the many scientists who have contributed to the national database (MEDS) over the years. We also thank D. Senciall and J. S. Kennedy for data processing and computer software support. This work was supported through the Government of Canada, Department of Fisheries and Oceans Strategic Science Fund (SSF) to the Ocean Climate Program (OCP).

\section{References}

AKENHEAD, S. 1986. Water retention over the Flemish Cap. S. Skreslet (ed.) The role of freshwater outflow in coastal marine systems. Springer-Verlag, New York, NY. p. 283-293.

ANDERSON, J. T. 1984. Early life history of redfish (Sebastes sp.) on Flemish Cap. Can. J. Fish. Aquat. Sci., 41(7): 1106-1116.

1992. The feeding ecology of larval and pelagic juvenile redfish (Sebastes spp.) on Flemish Cap $\left(47^{\circ} \mathrm{N}\right.$, $\left.45^{\circ} \mathrm{W}\right)$. Phd. Thesis, University of British Columbia.

BUZDALIN, YU. I., and A. A. ELIZAROV. 1962. Hydrological conditions in the Newfoundland banks and Labrador areas in 1960. In: Soviet Fisheries Investigations in the Northwest Atlantic. VNIRO-PINRO. Moskva. (Transl. For US Dep. Int. Sci. Found. Washington. D. C. by Isael Prog. Sci. Transl., 1963), p 152-168.

COLBOURNE, E. MS 1993. Oceanographic conditions on the Flemish Cap during the summer 1993, with comparisons to the long-term average. NAFO SCR. Doc., No. 107, Serial No. N2300, 16 p.

COLBOURNE, E. B., J. HELBIG, and D. CUMMINGS. 1993. Improved ADCP performance using a hydrodynamically designed boom mount. J. Atmospheric and Oceanic Technology, 10(4): 629-636.

COLBOURNE, E. B., and C. FITZPATRICK. 1994. Temperature, salinity and density at Station 27 from 1978 to 1993. Can. Tech. Rep. Hydrogr. Ocean Sci., 159: v $+117 \mathrm{p}$.

COLBOURNE, E.B. S. NARAYANAN, and S. PRINSENBERG. 1994. Climate change and environment conditions in the Northwest Atlantic during the period 1970-1993. ICES Mar. Sci. Symp., 198: 311-322.

COLBOURNE, E. MS 1995. Oceanographic conditions on the Flemish Cap during the summer 1995, with comparisons to the 1961-1990 average. NAFO SCR Doc., No. 102, Serial No. N2625, 12 p.

MS 1996. Oceanographic conditions on the Flemish Cap during the summer 1996, with comparisons to the previous year and the 1961-1990 average. NAFO SCR. Doc., No. 87, Serial No. N2770, 12 p.

COLBOURNE, E. B., and D. R. SENCIALL. 1996. Temperature, salinity and sigma-t along the standard Flemish Cap transect. Can. Tech. Rep. Hydrogr. Ocean Sci., 172: v +222p.

COLBOURNE, E. MS 1997. Oceanographic conditions on the Flemish Cap during the summer 1997, with comparisons to the previous year and the 1961-1990 average. NAFO SCR Doc., No. 84, Serial No. N2930, 15 p.

COLBOURNE, E. MS 1998. Oceanographic conditions on the Flemish Cap during the summer 1998, with comparisons to the previous year and the 1961-1990 average. NAFO SCR Doc., No. 86, Serial No. N3087, $15 \mathrm{p}$.

DICKSON, R.R., J. MEINCKE, S. A. MALMBERG, and A. J. LEE. 1988. The "Great Salinity Anomaly" in the northern North Atlantic 1968-82. Progr. Oceanogr., 20: $103-151$.

DRINKWATER, K. F., and R. W. TRITES. 1986. Monthly means of temperature and salinity in the Grand Banks region. Can. Tech. Rep. Fish. Aquat. Sci., 1450: iv+111 p.

DRINKWATER, K. F. 1996. Atmospheric and oceanic 
variability in the Northwest Atlantic during the 1980s and early-1990s. J. Northw. Atl. Fish. Sci., 18: 77-97.

DRINKWATER, K. F., E. COLBOURNE, and D. GILBERT. 1996. Overview of environmental conditions in the Northwest Atlantic in 1995. NAFO Sci. Coun. Studies, 27: 1-37.

GILL, A. E. 1982. Atmosphere-Ocean dynamics. Academic Press, New York.

HILL, H. W., P. G. W. JONES, J. W. RAMSTER, and A. R. FOLKARD. MS 1973. A note on the Labrador and Atlantic Currents to the east of Newfoundland Grand Bank. Annu. Meet. Int. Comm. Atlant. Fish. 1973, Res. Doc., No. 116, Serial No. 3082.

HUPPERT, H. E., and K. BRYAN. 1976. Topographically generated eddies. Deep -Sea Res., 23: 655-679.

ISEMER, H. J., and L. HASSE. 1987. The Bunker Climate Atlas of the North Atlantic Ocean. Vol. 2: Air-Sea Interactions, Springer-Verlag, New York, $252 \mathrm{p}$.

ISEMER, H. J., J. WILLEBRAND, and L. HASSE. 1989. Fine adjustments of large scale air-sea energy flux parameterizations by direct estimates of ocean heat transport. J. Climate, 2: 1173-1184.

KUDLO, B. P., and V. V. BURMAKIN. 1972. Water circulation in the South Labrador and Newfoundland areas in 1970-71. ICNAF Redbook 1972 (iii): 22-33.

KUDLO, B. P., and V. A. BOROVKOV. MS 1975. Circulation of waters in the ICNAF area in 1973-1974. ICNAF Res. Doc., No. 79, Serial No. 3506, 12 p.

KUDLO, B. P., V. A. BOROVKOV, and N. G. SAPRONETSKAYA. 1984. Water circulation patterns on the Flemish Cap from observations in 1977-82. NAFO Sci.
Coun. Studies, 7: 27-37.

LODER, J. W., C. K. ROSS, and P. C. SMITH. 1988. A space and time-scale characterization of the circulation and mixing over submarine banks, with application to the Northwestern Atlantic Continental Shelf. Can. J. Fish. Aquat. Sci., 45: 1860-1885.

PETRIE, B., J. LODER, S. AKENHEAD, and J. LAZIER. 1991. Temperature and salinity variability on the eastern Newfoundland Shelf: the annual harmonic. AtmosphereOcean, 29: 14-36.

ROGERS, J. C. 1984. The association between the North Atlantic oscillation and the southern oscillation in the Northern Hemisphere. Mon. Weather, Rev. 112: 1999_ 2105.

ROSS, C. K. 1981. Drift of satellite-tracked buoys on the Flemish Cap, 1970-80. NAFO Sci. Coun. Studies, 1: $47-50$.

SMITH, E. H., F. M. SOULE, and O. MOSBY. 1937. The Marion and General Green expeditions to Davis Strait and Labrador Sea. Bull. U.S. Coast Guard, No. 19, 259 p.

STEIN, M. 1996. Flemish Cap - A review on research activities with focus on oceanographic conditions. NAFO Sci. Coun. Studies, 25: 1-24.

TEMPLEMAN, W. 1976. Biological and oceanographic background of Flemish Cap as an area for research on the reasons for year-class success and failure in cod and redfish. ICNAF Res. Bull., 12: 91-117.

UMOH, J. U., J. W. LODER, and B. PETRIE. 1995. The role of air-sea heat fluxes in annual and interannual ocean temperature variability on the Eastern Newfoundland Shelf. Atmosphere-Ocean, 33: 531-568. 